\title{
PENALARAN MATEMATIS ANTARA SISWA LAKI-LAKI DAN PEREMPUAN YANG BERGAYA KOGNITIF IMPULSIF DALAM MEMECAHKAN MASALAH MATEMATIKA
}

\author{
${ }^{1}$ Muh. Syarwa Sangila, ${ }^{1}$ Sri Anandari Safaria, ${ }^{1}$ Iin Rizqy Rahayu ${ }^{2}$ Asran
}

${ }^{1}$ Fakultas Tarbiyah dan Ilmu Keguruan, Institut Agama Islam Negeri

Kendari. Jl. Sultan Qaimuddin No. 17 Baruga, Kendari, Indonesia

${ }^{2}$ Fakultas Keguruan dan Ilmu Pendidikan, Universitas Halu Oleo,

Jl. H.E.A Mokodompit No. 1 Andonohu Kendari, Indonesia

Email:syarwa1990@gmail.com; srianandarisafaria@gmail.com ; asran_math@yahoo.co.id

\begin{abstract}
Abstrak
Penelitian ini bertujuan mengungkap profil penalaran matematis siswa yang bergaya kognitif impulsif dalam memecahkan masalah matematika. Penelitian ini adalah penelitian eksploratif. Subjek penelitian ini adalah dua orang siswa bergaya kognitif impulsif (satu laki-laki dan satu perempuan). Intrumen yang digunakan yaitu tes gaya kognitif, tugas pemecahan masalah dan wawancara. Setelah dilakukan analisis, disimpulkan bahwa penalaran matematis siswa dalam memecahkan masalah matematika adalah: (1) memahami masalah: menyajikan pernyataan secara lisan tentang apa yang dipahami, melakukan manipulasi matematika, memeriksa kebenaran argumen yang diungkapkan dan siswa laki-laki tidak dapat menyimpulkan tentang apa yang dipahami pada masalah; (2) membuat rencana pemecahan masalah: membuat gambar sebagai representasi dari masalah, melakukan manipulasi matematis saat memikirkan rencana pemecahan masalah, memeriksa kebenaran rencana yang dipikirkan dan tidak menyimpulkan apa yang dipikirkan dalam membuat rencana pemecahan masalah (3) melaksanakan rencana pemecahan masalah: menyajikan pernyataan secara tertulis yang telah dipikirkan, melakukan manipulasi matematika, menyatakan kebenaran apa yang ditulis dan tidak menyimpulkan hasil pemecahan masalah;(4) memeriksa kembali hasil pemecahan masalah: tidak melakukan manipulasi matematis saat memeriksa kembali hasil pemecahan masalah. Hasil penelitian ini merekomendasikan kepada guru untuk siswa yang bergaya kognitif impulsif, hendaknya diberikan perhatian khusus dengan sering memberikan latihan soal, langkah-langkah pemecahannya, serta mengarahkan agar tidak tergesa-gesa menyelesaikan soal.
\end{abstract}

Kata Kunci: Gaya kognitif impulsif; penalaran matematis; pemecahan masalah matematika 


\begin{abstract}
This study aims to reveal the profile of students' mathematical reasoning that is impulsive cognitive style in solving mathematical problems. This research is exploratory research. The subjects of this study were two students in cognitive impulsive style (one male and one female). The instruments used were cognitive style tests, problem solving assignments and interviews. After the analysis is concluded, students' mathematical reasoning in solving mathematical problems is: (1) understanding the problem: presenting statements verbally about what is understood, doing mathematical manipulations, checking the truth of the arguments expressed and one does not conclude about what is understood in the problem; (2) making a problemsolving plan: making an image as a representation of the problem, doing mathematical manipulation when thinking about a problem-solving plan, checking the truth of the plan in mind and not concluding what is being thought in making a problem-solving plan (3) implementing a problem-solving plan: in writing that has been thought about, doing mathematical manipulation, stating the truth of what is written and not concluding the results of problem solving; (4) re-examine the results of problem solving: do not do mathematical manipulation when re-examining the results of problem solving. The results of this study recommend to teachers for students who are impulsive cognitive style, should be given special attention by often giving practice questions, the steps to solving them, and directing them to not rush to solve the problem.
\end{abstract}

Keywords: Impulsive cognitive style; mathematical problem solving, mathematical reasoning

\title{
A. PENDAhULUAN
}

Kualitas suatu bangsa sangat ditentukan oleh sumber daya manusia dari bangsa itu. Salah satu upaya yang dapat dilakukan untuk meningkatkan kualitas sumber daya manusia adalah peningkatan mutu pendidikan, baik prestasi belajar siswa maupun kemampuan guru dalam melaksanakan proses pembelajaran. Ukuran kualitas sumber daya manusia yang umum digunakan adalah Indeks Pembangunan Manusia (IPM) atau disebut juga dengan Human Development Index (HDI). Harapan masyarakat agar pendidikan berperan penting dalam pencapaian sumber daya manusia yang handal, tampaknya belum memberikan hasil yang maksimal. Berdasarkan Release United Nations Development Programme (2014) menyebutkan bahwa Indeks Pembangunan Manusia Indonesia berada pada peringkat 108 dari 187 Negara, lebih rendah dibandingkan dengan beberapa negara Asia Tenggara seperti Singapura (9), Brunai Darussalam (30), Malaysia (62) dan Thailand (89) (Mudlofir, 2015). 
Penggunaan model mengajar yang tidak sesuai dengan materi yang diajarkan cenderung menunjukkan hasil belajar siswa kurang optimal (Sangila, 2017). Hal ini disebabkan oleh pemahaman yang masih belum memadai dan paradigma pembelajaran yang belum sesuai dengan tindakan yang seharusnya. Penelitian membuktikan bahwa perbedaan tentang paradigma pembelajaran ternyata berdampak pada hasil belajar peserta didik. Perbandingan hasil tes TIMSS dan PISA pada beberapa periode tes menunjukkan bahwa peserta didik di Jepang memperoleh hasil yang jauh lebih tinggi daripada peserta didik di Jerman (kelompok sedang) dan Amerika (kelompok rendah). Guru di Amerika percaya bahwa pembelajaran terjadi dengan penguasan materi secara bertahap, sehingga pembelajaran perlu dilakukan sedikit demi sedikit dengan meminimalkan kesalahan. Sedangkan guru di Jepang percaya bahwa peserta didik akan belajar dengan baik jika dimulai dengan berupaya memecahkan permasalahan, kemudian berdiskusi bersama untuk memecahkan permasalahan tersebut (Sani, 2013)

Berdasarkan dokumen National Council of Teaching of Mathematics (NCTM) direkomendasikan pentingnya para siswa memiliki kemampuan penalaran dan pemecahan masalah matematika. Penalaran merupakan cara berpikir siswa yang logis secara pendekatan induktif yaitu pembelajaran memberikan bukti yang logis untuk mencapai kesimpulan dan pembelajaran deduktif yaitu konsep-konsep penyelesaian masalah (Bernard, 2015). Salah satu bentuk pengorganisasian pemecahan masalah matematika adalah seperti yang dikemukakan Polya (1978) yang meliputi 4 langkah, yakni: memahami masalah; (2) menentukan rencana pemecahan masalah; mengerjakan sesuai rencana; (4) melihat kembali hasil yang diperoleh.

Inti studi TIMSS (Trends in International Mathematics and Science Study) dan PISA (Programme for International Students Assessment) terletak pada kekuatan penalaran matematis siswa serta kemampuan menerapkannya dalam kehidupan sehari-hari. Hal ini menunjukkan kelemahan siswa dalam menghubungkan konsep-konsep matematika yang bersifat formal dengan permasalahan dalam dunia nyata. Memperhatikan rendahnya kemampuan siswa Indonesia dalam survei tersebut, Pemerintah Indonesia, dalam hal ini Kementerian Pendidikan dan Kebudayaan, sebenarnya telah mengantisipasinya dengan melakukan beberapa perubahan kurikulum. Pada kurun waktu tahun 2000 sampai sekarang, telah ada tiga jenis kurikulum yang diberlakukan, yaitu kurikulum 2004, kurikulum 2006, dan kurikulum 2013 (Murtiya, 2015). Walaupun berganti kurikulum, ternyata belum mampu mengangkat prestasi siswa di forum internasional. Pengamatan sementara menunjukkan bahwa meskipun kurikulum berganti, tetapi fungsi dan peran guru dalam pembelajaran matematika, khususnya terkait cara menyampaikan materi pelajaran tidak pernah berubah. 
Memperhatikan apa yang akan diperoleh siswa dengan belajar memecahkan masalah, maka wajarlah jika pemecahan masalah adalah bagian yang sangat penting,bahkan paling penting dalam belajar matematika. Hal ini karena pada dasarnya salah satu tujuan belajar matematika bagi siswa adalah agar ia mempunyai kemampuan atau ketrampilan dalam memecahkan masalah atau soal-soal matematika, sebagai sarana baginya untuk mengasah penalaran yang cermat, logis, kritis, analitis, dan kreatif (Sumartini, 2015).

Kemampuan penalaran dan pemecahan masalah matematis memiliki peranan yang sangat penting dalam tercapainya tujuan pendidikan matematika di sekolah. Penalaran merupakan suatu konsep umum yang menunjuk pada salah satu proses berpikir untuk sampai kepada suatu kesimpulan sebagai pernyataan baru dari beberapa pernyataan lain yang telah diketahui (Yeni, 2016). Penalaran juga merupakan pola berfikir yang tinggi yang mencakup kemampuan berfikir secara logis dan sistematis. Sejalan dengan itu penalaran merupakan suatu cara berfikir untuk menarik kesimpulan, baik kesimpulan yang bersifat umum yang ditarik dari hal-hal yang bersifat khusus maupun halhal yang bersifat umum dapat menjadi kesimpulan yang bersifat khusus (Yenni, 2016).

Memecahkan masalah merupakan aktivitas mental tingkat tinggi, sehingga pengembangan keterampilan pemecahan masalah dalam pembelajaran matematika tidak mudah. Siswa dikatakan telah mampu memecahkan suatu masalah jika siswa telah mampu memahami soal, mampu merencanakan pemecahan masalah tersebut, dan mampu melakukan perhitungan serta memeriksa kembali hasil perhitungan yang telah dilakukan (Nurnadilah, 2014).

Banyak ahli yang mengatakan pentingnya belajar pemecahan masalah dalam matematika. Hasil-hasil penelitian menunjukkan bahwa strategi-strategi pemecahan masalah yang umumnya dipelajari dalam pelajaran matematika, dalam hal-hal tertentu, dapat ditransfer dan diaplikasikan dalam situasi pemecahan masalah yang lain. Branca (1980) mengemukakan bahwa kemampuan pemecahan masalah adalah jantungnya matematika (Efendi, 2012). Hal ini sejalan dengan NCTM yang menyatakan bahwa pemecahan masalah merupakan bagian integral dalam pembelajaran matematika, sehingga hal tersebut tidak boleh dilepaskan dari pembelajaran matematika.

Penalaran dibagi menjadi dua, yaitu penalaran induktif dan penalaran deduktif. Penalaran induktif adalah proses penalaran yang menurunkan prinsip atau aturan umum dari pengamatan hal-hal atau contoh-contoh kasus. Sementara itu, penalaran deduktif adalah proses penalaran dari pengetahuan prinsip atau pengalaman yang umum yang menuntun kita memperoleh kesimpulan untuk sesuatu yang khusus (Ramdani, 2012).

Kemampuan penalaran matematis yang digunakan memberikan penjelasan terhadap model, gambar, fakta, sifat, hubungan, atau pola yang ada, 
mengikuti argumen-argumen logis dan menarik kesimpulan logis (Ramdani, 2012). Kemampuan penalaran matematis merupakan suatu kebiasaan otak seperti halnya kebiasaan lain yang harus dikembangkan secara konsisten menggunakan berbagai macam konteks, mengenal penalaran dan pembuktian merupakan aspek-aspek fundamental dalam matematika. Dengan penalaran matematis, siswa dapat mengajukan dugaan kemudian menyusun bukti dan melakukan manipulasi terhadap permasalahan matematika serta menarik kesimpulan dengan benar dan tepat (Turmudi, 2008).

Ada beberapa teori yang menyebutkan bahwa laki-laki dan perempuan memiliki perbedaan dalam beberapa hal, tetapi tidak menyebutkan perbedaan kemampuan penalaran matematis antara anak laki-laki dan anak perempuan dalam memecahkan masalah matematika. Perbedaan gender tidak berperan dalam kesuksesan belajar, dalam arti tidak dapat disimpulkan dengan jelas apakah laki-laki atau perempuan lebih baik dalam belajar matematika (Hightower, 2003).

Pengaruh gender terhadap pembelajaran matematika telah banyak diteliti para ahli. Tujuan utamanya adalah mendorong kesamaan dalam belajar antara laki-laki dan perempuan. Artikel pertama mengenai gender di Journal for Research in Mathematics Education (JRME) ditulis oleh Fennema tahun 1974 yang berjudul Mathematics Learning and Sexes. Dua dekade kemudian, Fennema melakukan metaanalisis dan mengambil kesimpulan dari hasil-hasil penelitian mengenai gender dan matematika yang telah diterbitkan di JRME. Salah satu kesimpulannya yaitu perbedaan gender dalam matematika cenderung menurun, dan perbedaan gender dalam matematika beragam dalam sosial-ekonomi dan etnik, sekolah serta guru (Fennema \& Hart, 1994). Hasil penelitian lain menunjukkan bahwa antara siswa berjenis kelamin laki-laki dan perempuan pada umumnya kemampuannya sama (Lestari, 2013).

Dari beberapa uraian diatas, profil penalaran matematis seseorang dalam memecahkan masalah akan dipengaruhi oleh gaya kognitif orang yang bersangkutan. Jadi, sangat dimungkinkan terjadi perbedaan profil penalaran matematis siswa impulsif dalam memecahkan masalah matematika antara siswa laki-laki dan siswa perempuan.

\section{B. METODE PENELITIAN}

Jenis penelitian ini adalah penelitian eksploratif. Untuk mendapatkan deskripsi data secara mendalam tentang penalaran matematis siswa dalam memecahkan masalah matematika, siswa diberi tugas pemecahan masalah matematika yang diikuti wawancara. Pada saat wawancara, siswa diminta untuk menjelaskan pemecahan masalah yang dilakukan sesuai langkahlangkah pemecahan masalah menurut Polya (1973). Sebelum diberi tugas pemecahan masalah, siswa melakukan tes gaya kognitif yang dikembangkan oleh Warli (2010) yang disebut MFFT (Matching Familiar Figure Test). 
Pemilihan subjek penelitian ini mengacu pada tujuan penelitian, yaitu untuk mengungkapkan penalaran matematis siswa kelas XI, MIA dan SMA Negeri 10 Kendari yang bergaya kognitif impulsif dalam memecahkan masalah matematika antara laki-laki dan perempuan. Oleh sebab itu, maka subjek penelitian ini adalah siswa-siswa kelas XI, MIA dan SMA Negeri 10 Kendari yang bergaya kognitif impulsif yang berjenis kelamin laki-laki dan yang berjenis kelamin perempuan.

Instrumen dalam penelitian ini ada dua macam, yaitu instrumen utama dan instrumen bantu. Instrumen utama adalah peneliti sendiri, sedangkan instrumen bantu ada 3 (tiga) macam, yaitu: instrumen gaya kognitif yang berisi gambar-gambar, tugas pemecahan masalah dan pedoman wawancara. Untuk mengumpulkan data dalam penelitian ini, akan digunakan teknik pemberian tes dan wawancara. Analisis data dalam penelitian ini mengikuti model analisis Miles dan Huberman (Alhojailan, 2012).

Proses analisis data menurut Miles dan Huberman terdiri dari tiga langkah, yaitu: (1) reduksi data, (2) penyajian data, dan (3) penafsiran data dan penarikan kesimpulan. Penafsiran dan penarikan kesimpulan. Data yang telah disajikan kemudian ditafsirkan dan disimpulkan. Kesimpulan dapat berupa deskripsi atau gambaran sesuatu objek yang sebelumnya masih belum jelas, sehingga setelah diteliti menjadi jelas.

\section{HASIL PENELITIAN}

\section{Subjek Pertama Impulsif Laki-Laki (S1IL)}

\section{a. Tahap memahami masalah}

Cuplikan hasil wawancara dan pengamatan masalah 1 dan masalah 2 pada tahap memahami masalah dipaparkan dan divalidasi. Validasi dilakukan untuk memperoleh data kredibel dengan cara membandingkan data hasil wawancara dan pengamatan masalah 1 dan 2. Paparan dan validasi data hasil wawancara dan pengamatan masalah 1 dan masalah 2 disajikan pada Tabel 1.

Tabel 1 Paparan dan Validasi Data Hasil Wawancara dan Pengamatan Masalah 1 dan 2 pada Tahap Memahami Masalah untuk S1IL

\begin{tabular}{|c|c|}
\hline $\begin{array}{c}\text { Data Hasil Wawancara dan Pengamatan } \\
\text { Tahap Memahami Masalah } 1\end{array}$ & $\begin{array}{c}\text { Data Hasil Wawancara dan Pengamatan } \\
\text { Tahap Memahami Masalah } 2\end{array}$ \\
\hline $\begin{array}{l}\text { Pada saat memahami masalah 1 S1IL: } \\
\text { membaca masalah dalam hati sebanyak dua } \\
\text { kali, menyatakan belum memahami } \\
\text { masalah dan membaca lagi masalah dalam } \\
\text { hati, menyatakan sudah memahami } \\
\text { masalah, mengungkapkan apa yang } \\
\text { dipahami pada masalah, menyatakan apa } \\
\text { yang ditanyakan pada masalah, yaitu } \\
\text { ukuran kotak dan menjelaskan apa yang } \\
\text { dimaksud dengan ukuran kotak, }\end{array}$ & $\begin{array}{l}\text { Pada saat memahami masalah } 2 \text { S1IL: } \\
\text { membaca masalah dalam hati sebanyak dua } \\
\text { kali, menyatakan belum memahami } \\
\text { masalah dan membaca lagi masalah dalam } \\
\text { hati, menyatakan sudah memahami } \\
\text { masalah, mengungkapkan apa yang } \\
\text { dipahami pada masalah, menyatakan apa } \\
\text { yang ditanyakan pada masalah, yaitu } \\
\text { ukuran kotak dan menjelaskan apa yang } \\
\text { dimaksud dengan ukuran kotak, }\end{array}$ \\
\hline
\end{tabular}


menyatakan benar yang diungkapkan tentang apa yang diketahui dan yang ditanyakan dalam masalah, tidak dapat menyimpulkan tentang apa yang dipahami pada masalah, menyatakan tidak ada lagi hal lain yang diketahui selain yang diungkapkan. menyatakan benar yang diungkapkan tentang apa yang diketahui dan yang ditanyakan pada masalah, tidak dapat menyimpulkan tentang apa yang dipahami pada masalah, Menyatakan tidak ada lagi hal lain yang diketahui selain yang diungkapkan.

Berdasarkan paparan data S1IL pada Tabel 1 di atas, dapat disimpulkan bahwa ada konsistensi S1IL dalam memahami masalah 1 dan 2, sehingga dapat dikatakan bahwa data S1IL dalam memahami masalah adalah kredibel.

\section{b. Tahap membuat rencana pemecahan masalah}

Cuplikan hasil wawancara dan pengamatan masalah 1 dan masalah 2 pada tahap membuat rencana pemecahan masalah dipaparkan dan divalidasi. Validasi dilakukan untuk memperoleh data kredibel dengan cara membandingkan data hasil wawancara dan pengamatan masalah 1 dan 2 . Paparan dan validasi data hasil wawancara dan pengamatan masalah 1 dan 2 disajikan pada Tabel 2 berikut.

Tabel 2 Paparan dan Validasi Data Hasil Wawancara dan Pengamatan Masalah 1 dan 2 pada Tahap Membuat Rencana Pemecahan Masalah untuk S1IL

\begin{tabular}{|c|c|}
\hline $\begin{array}{c}\text { Data Hasil Wawancara dan Pengamatan } \\
\text { Tahap Membuat Rencana Pemecahan } \\
\text { Masalah } 1\end{array}$ & $\begin{array}{c}\text { Data Hasil Wawancara dan Pengamatan } \\
\text { Tahap Membuat Rencana Pemecahan } \\
\text { Masalah } 2\end{array}$ \\
\hline $\begin{array}{l}\text { Pada saat membuat rencana pemecahan } \\
\text { masalah 1, S1IL melakukan hal-hal } \\
\text { berikut: membuat gambar sebagai } \\
\text { representasi dari masalah, tidak dapat } \\
\text { mengungkapkan nama sudut yang } \\
\text { dipotong pada gambar sebelum diberikan } \\
\text { penjelasan tambahan dan dapat } \\
\text { mengungkapkan namanya setelah } \\
\text { diberikan penjelasan tambahan, } \\
\text { menentukan ukuran kotak agar } \\
\text { volumenya maksimum dengan cara } \\
\text { menentukan ukuran panjang, lebar dan } \\
\text { tinggi kotak, selanjutnya menentukan } \\
\text { persamaan volume kotak, kemudian } \\
\text { diturunkan, memberikan alasan mengapa } \\
\text { persamaan volume kotak harus } \\
\text { diturunkan, menyatakan bahwa rencana } \\
\text { untuk menentukan volume kotak sudah } \\
\text { benar dan tidak dapat menyimpulkan } \\
\text { tentang apa yang dipikirkan tentang } \\
\text { rencana penyelesaian masalah yang } \\
\text { diberikan. }\end{array}$ & $\begin{array}{l}\text { Pada saat membuat rencana pemecahan } \\
\text { masalah 2, S1IL melakukan hal-hal berikut: } \\
\text { membuat gambar sebagai representasi dari } \\
\text { masalah, dapat mengungkapkan nama sudut } \\
\text { yang dipotong pada gambar, menentukan } \\
\text { ukuran kotak agar volumenya maksimum } \\
\text { dengan cara menentukan ukuran panjang, } \\
\text { lebar dan tinggi kotak, selanjutnya } \\
\text { menentukan persamaan volume kotak, } \\
\text { kemudian diturunkan, memberikan alasan } \\
\text { mengapa persamaan volume kotak harus } \\
\text { diturunkan, menyatakan bahwa rencana untuk } \\
\text { menentukan volume kotak sudah benar dan } \\
\text { tidak dapat menyimpulkan tentang apa yang } \\
\text { dipikirkan tentang rencana penyelesaian } \\
\text { masalah yang diberikan. }\end{array}$ \\
\hline
\end{tabular}


Berdasarkan paparan data S1IL pada Tabel 2 di atas, dapat disimpulkan bahwa ada konsistensi S1IL dalam membuat rencana pemecahan masalah 1 dan masalah 2, sehingga dapat dikatakan bahwa data S1IL dalam membuat rencana pemecahan masalah adalah kredibel.

\section{c. Tahap melaksanakan rencana pemecahan masalah}

Cuplikan hasil wawancara dan pengamatan masalah 1 dan 2 pada tahap melaksanakan rencana pemecahan masalah dipaparkan dan divalidasi. Validasi dilakukan untuk memperoleh data kredibel dengan cara membandingkan data hasil wawancara dan pengamatan masalah 1 dan 2 . Paparan dan validasi data hasil wawancara dan pengamatan masalah 1 dan 2 disajikan pada Tabel 3 berikut.

Tabel 3. Paparan dan Validasi Data Hasil Wawancara dan Pengamatan Masalah 1 dan 2 pada Tahap Melaksanakan Rencana Pemecahan Masalah untuk S1IL

\begin{tabular}{|c|c|}
\hline $\begin{array}{c}\text { Data Hasil Wawancara dan Pengamatan } \\
\text { Tahap Melaksanakan Rencana Pemecahan } \\
\text { Masalah } 1\end{array}$ & $\begin{array}{c}\text { Data Hasil Wawancara dan Pengamatan } \\
\text { Tahap Melaksanakan Rencana Pemecahan } \\
\text { Masalah } 2\end{array}$ \\
\hline $\begin{array}{l}\text { Pada saat melaksanakan rencana pemecahan } \\
\text { masalah 1, S1IL melakukan hal-hal berikut: } \\
\text { tidak memahami untuk menuliskan apa yang } \\
\text { dipikirkan dan memahami setelah diberikan } \\
\text { penjelasan tambahan, menghitung volume } \\
\text { kotak, menyatakan bahwa setiap langkah } \\
\text { yang ditulis sudah benar dengan cara } \\
\text { melihat kembali apa yang ditulis, } \\
\text { menyatakan syarat untuk memperoleh } \\
\text { volume maksimum yaitu turunan pertama } \\
\text { dari persamaan volumenya sama dengan nol } \\
\text { dan menurunkan persamaan volume kotak, } \\
\text { menyatakan bahwa untuk memperoleh nilai } \\
\text { x dilakukan dengan cara memfaktorkan dan } \\
\text { persamaan volume yang sudah diturunkan } \\
\text { difaktorkan, menentukan cara untuk } \\
\text { memperoleh volume maksimum, } \\
\text { menuliskan volume kotak yang maksimum } \\
\text { dan menentukan ukuran kotak yang } \\
\text { mengakibatkan volume kotak maksimum, } \\
\text { menyatakan bahwa volume dan ukuran } \\
\text { kotak yang mengakibatkan volume } \\
\text { maksimum sudah benar, tidak dapat } \\
\text { menyimpulkan tentang penyelesaian } \\
\text { masalah yang diberikan. }\end{array}$ & $\begin{array}{l}\text { Pada saat melaksanakan rencana } \\
\text { pemecahan masalah 2, S1IL melakukan hal- } \\
\text { hal berikut: menuliskan apa yang } \\
\text { dipikirkan, menghitung volume kotak, } \\
\text { menyatakan bahwa setiap langkah yang } \\
\text { ditulis sudah benar dengan cara melihat } \\
\text { kembali apa yang ditulis, menyatakan } \\
\text { syarat untuk memperoleh volume } \\
\text { maksimum yaitu turunan pertama dari } \\
\text { persamaan volumenya sama dengan nol dan } \\
\text { menurunkan persamaan volume kotak, } \\
\text { menyatakan bahwa untuk memperoleh nilai } \\
x \text { dilakukan dengan cara memfaktorkan dan } \\
\text { persamaan volume yang sudah diturunkan } \\
\text { difaktorkan, menentukan cara untuk } \\
\text { memperoleh volume maksimum, } \\
\text { menuliskan volume kotak yang maksimum } \\
\text { dan menentukan ukuran kotak yang } \\
\text { mengakibatkan volume kotak maksimum, } \\
\text { menyatakan bahwa volume dan ukuran } \\
\text { kotak yang mengakibatkan volume } \\
\text { maksimum sudah maksimum, tidak dapat } \\
\text { menyimpulkan tentang penyelesaian } \\
\text { masalah yang diberikan. }\end{array}$ \\
\hline
\end{tabular}

Berdasarkan paparan data S1IL pada Tabel 3 di atas, dapat disimpulkan bahwa ada konsistensi S1IL dalam melaksanakan rencana pemecahan masalah 
1 dan 2, sehingga dapat dikatakan bahwa data S1IL dalam melaksanakan rencana pemecahan masalah adalah kredibel.

\section{d. Tahap memeriksa kembali hasil pemecahan masalah}

Cuplikan hasil wawancara dan pengamatan masalah 1 dan 2 pada tahap memeriksa kembali hasil pemecahan masalah dipaparkan dan divalidasi. Validasi dilakukan untuk memperoleh data kredibel dengan cara membandingkan data hasil wawancara dan pengamatan masalah 1 dan 2 . Paparan dan validasi data hasil wawancara dan pengamatan masalah 1 dan 2 disajikan pada Tabel 4 berikut.

Tabel 4. Paparan dan Validasi Data Hasil Wawancara dan Pengamatan Masalah 1 dan

Masalah 2 pada Tahap Memeriksa Kembali Hasil Pemecahan Masalah untuk S1IL

Data Hasil Wawancara dan Pengamatan Tahap Memeriksa Kembali Hasil Pemecahan Masalah 1

Pada saat memeriksa kembali hasil pemecahan masalah 1, S1IL melakukan halhal berikut: menelusuri kembali apa yang dikerjakan dari awal, tidak mengatakan bahwa cara memeriksa kembali hasil pemecahan masalah sudah benar, menyimpulkan bahwa hasil yang diperoleh sudah sesuai dan sudah benar.
Data Hasil Wawancara dan Pengamatan Tahap Memeriksa Kembali Hasil Pemecahan Masalah 2 Pada saat memeriksa kembali hasil pemecahan masalah 2, S1IL melakukan hal-hal berikut: menelusuri kembali dari awal apa yang dikerjakan, tidak mengatakan bahwa cara memeriksa kembali hasil pemecahan masalah sudah benar, menyimpulkan bahwa hasil yang diperoleh sudah benar.

Data S1IL pada tahap memeriksa kembali hasil pemecahan masalah yang telah dipaparkan di atas adalah data tereduksi, yaitu data yang sudah dipilih, dikelompokan berdasarkan kategori pada pentahapan Polya. Berdasarkan paparan data S1IL pada Tabel 4 di atas, dapat disimpulkan bahwa ada konsistensi S1IL dalam memeriksa kembali hasil pemecahan masalah 1 dan masalah 2, sehingga dapat dikatakan bahwa data S1IL dalam memeriksa kembali hasil pemecahan masalah adalah kredibel.

\section{Subjek Kedua Impulsif Perempuan (S2IP)}

\section{a. Tahap memahami masalah}

Cuplikan hasil wawancara dan pengamatan masalah 1 dan 2 pada tahap memahami masalah dipaparkan dan divalidasi. Validasi dilakukan untuk memperoleh data kredibel dengan cara membandingkan data hasil wawancara dan pengamatan masalah 1 dan masalah 2. Paparan dan validasi data hasil wawancara dan pengamatan masalah 1 dan 2 disajikan pada Tabel 5 berikut. 
Tabel 5. Paparan dan Validasi Data Hasil Wawancara dan Pengamatan Masalah 1 dan 2 pada Tahap Memahami Masalah untuk S2IP

\begin{tabular}{|c|c|}
\hline $\begin{array}{c}\text { Data Hasil Wawancara dan Pengamatan } \\
\text { Tahap Memahami Masalah } 1\end{array}$ & $\begin{array}{c}\text { Data Hasil Wawancara dan Pengamatan } \\
\text { Tahap Memahami Masalah } 2 \\
\end{array}$ \\
\hline $\begin{array}{l}\text { Pada saat memahami masalah 1, S2IP } \\
\text { melakukan hal-hal berikut: membaca } \\
\text { masalah dalam hati beberapa kali, } \\
\text { menyatakan belum memahami masalah } \\
\text { ketika hanya satu kali membaca masalah } \\
\text { dan menyatakan sudah memahami } \\
\text { masalah setelah membaca masalah } \\
\text { beberapa kali, mengungkapkan apa yang } \\
\text { dipahami pada masalah, menyatakan apa } \\
\text { yang ditanyakan pada masalah, } \\
\text { menyatakan ukuran kotak sebagai } \\
\text { panjang, lebar dan tinggi, menyatakan } \\
\text { bahwa yang diungkapkan tentang apa } \\
\text { yang diketahui dan yang diungkapkan } \\
\text { sudah benar, menyimpulkan apa yang } \\
\text { dipahami pada masalah. }\end{array}$ & $\begin{array}{l}\text { Pada saat memahami masalah 2, S2IP } \\
\text { melakukan hal-hal berikut: membaca } \\
\text { masalah dalam hati beberapa kali, } \\
\text { menyatakan belum memahami masalah } \\
\text { ketika hanya satu kali membaca masalah dan } \\
\text { menyatakan sudah memahami masalah } \\
\text { setelah membaca masalah beberapa kali, } \\
\text { mengungkapkan apa yang dipahami pada } \\
\text { masalah, menyatakan apa yang ditanyakan } \\
\text { pada masalah, menyatakan ukuran kotak } \\
\text { sebagai panjang, lebar dan tinggi, } \\
\text { menyatakan bahwa yang diungkapkan } \\
\text { tentang apa yang diketahui dan yang } \\
\text { diungkapkan sudah benar, menyimpulkan } \\
\text { apa yang dipahami pada masalah. }\end{array}$ \\
\hline
\end{tabular}

Berdasarkan paparan data S2IP pada Tabel 5 di atas, dapat disimpulkan bahwa ada konsistensi S2IP dalam memahami masalah 1 dan masalah 2, sehingga dapat dikatakan bahwa data S2IP dalam memahami masalah adalah kredibel.

\section{b. Tahap membuat rencana pemecahan masalah}

Cuplikan hasil wawancara dan pengamatan masalah 1 dan 2 pada tahap membuat rencana pemecahan masalah kemudian dipaparkan dan divalidasi. Validasi dilakukan untuk memperoleh data kredibel dengan cara membandingkan data hasil wawancara dan pengamatan masalah 1 dan 2 . Paparan dan validasi data hasil wawancara dan pengamatan masalah 1 dan masalah 2 disajikan pada Tabel 6 berikut.

Tabel 6. Paparan dan Validasi Data Hasil Wawancara dan Pengamatan Masalah 1 dan 2 pada Tahap Membuat Rencana Pemecahan Masalah untuk S2IP

\begin{tabular}{ll}
\hline $\begin{array}{c}\text { Data Hasil Wawancara dan Pengamatan } \\
\text { Tahap Membuat Rencana Pemecahan } \\
\text { Masalah 1 }\end{array}$ & $\begin{array}{c}\text { Data Hasil Wawancara dan Pengamatan } \\
\text { Tahap Membuat Rencana PemecahanMasalah } \\
2\end{array}$ \\
\hline $\begin{array}{l}\text { Pada saat membuat rencana pemecahan } \\
\text { masalah 1, S2IP melakukan hal-hal }\end{array}$ & $\begin{array}{l}\text { Pada saat membuat rencana pemecahan } \\
\text { masalah 2, S2IP melakukan hal-hal berikut: } \\
\text { berikut: membuat gambar tentang apa } \\
\text { yang dipahami pada masalah, }\end{array}$ \\
$\begin{array}{l}\text { membuat gambar tentang apa yang dipahami } \\
\text { pada masalah, menyatakan sudut yang } \\
\text { gambar sebagai variable x, menentukan }\end{array}$ & $\begin{array}{l}\text { dipotong pada gambar dengan variable x, } \\
\text { menentukan cara untuk memperoleh ukuran }\end{array}$ \\
$\begin{array}{l}\text { cara untuk memperoleh ukuran kotak } \\
\text { agar volume kotak maksimum, yaitu }\end{array}$ & $\begin{array}{l}\text { kotak agar volume kotak maksimum, yaitu } \\
\text { dengan cara menentukan ukuran panjang, }\end{array}$ \\
\hline
\end{tabular}




\begin{tabular}{|c|c|}
\hline $\begin{array}{l}\text { langkah selanjutnya untuk memperoleh } \\
\text { volume kotak masimum, yaitu } \\
\text { menentukan persamaan volume kotak } \\
\text { dan menurunkan persamaan volume } \\
\text { kotak, memberikan alasan mengapa } \\
\text { persamaan volume kotak harus } \\
\text { diturunkan dan menentukan syarat agar } \\
\text { volume kotak maksimum, menyatakan } \\
\text { bahwa apa yang dipikirkan untuk } \\
\text { menentukan ukuran kotak agar volume } \\
\text { kotak maksimum sudah benar dengan } \\
\text { cara melihat kembali soal, menyimpulkan } \\
\text { bahwa dari apa yang dipikirkan akan } \\
\text { diperoleh kotak yang volumenya } \\
\text { maksimum. }\end{array}$ & $\begin{array}{l}\text { lebar dan tinggi kotak, menentukan langkah } \\
\text { selanjutnya untuk memperoleh volume kotak } \\
\text { masimum, yaitu menentukan persamaan } \\
\text { volume kotak dan menurunkan persamaan } \\
\text { volume kotak, memberikan alasan mengapa } \\
\text { persamaan volume kotak harus diturunkan } \\
\text { dan menentukan syarat agar volume kotak } \\
\text { maksimum, menyatakan bahwa apa yang } \\
\text { dipikirkan untuk menentukan ukuran kotak } \\
\text { agar volume kotak maksimum sudah benar } \\
\text { dengan cara melihat kembali soal, } \\
\text { menyimpulkan bahwa dari apa yang } \\
\text { dipikirkan akan diperoleh kotak yang } \\
\text { volumenya maksimum. }\end{array}$ \\
\hline
\end{tabular}

Berdasarkan paparan data S2IP pada Tabel 6 di atas, dapat disimpulkan bahwa ada konsistensi S2IP dalam membuat rencana pemecahan masalah 1 dan 2, sehingga dapat dikatakan bahwa data S2IP dalam membuat rencana pemecahan masalah adalah kredibel.

\section{c. Tahap melaksanakan rencana pemecahan masalah}

Cuplikan hasil wawancara dan pengamatan masalah 1 dan 2 pada tahap melaksanakan rencana pemecahan masalah dipaparkan dan divalidasi. Validasi dilakukan untuk memperoleh data kredibel dengan cara membandingkan data hasil wawancara dan pengamatan masalah 1 dan masalah 2. Paparan dan validasi data hasil wawancara dan pengamatan masalah 1 dan 2 disajikan pada Tabel 7 berikut.

Tabel 7. Paparan dan Validasi Data Hasil Wawancara dan Pengamatan Masalah 1 dan Masalah 2 pada Tahap Melaksanakan Rencana Pemecahan Masalah untuk S2IP

Data Hasil Wawancara dan Pengamatan

Tahap Melaksanakan Rencana Pemecahan Masalah 1 Data Hasil Wawancara dan Pengamatan Tahap Melaksanakan Rencana Pemecahan Masalah 2

\begin{tabular}{ll}
\hline Pada saat melaksanakan rencana masalah 1, & Pada saat melaksanakan rencana masalah 2, \\
S2IP melakukan hal-hal berikut: menuliskan & S2IP melakukan hal-hal berikut: \\
apa yang dipirkan, yaitu ukuran dan volume & menuliskan apa yang dipirkan, yaitu ukuran \\
kotak, menyatakan bahwa setiap langkah & dan volume kotak, menyatakan bahwa \\
ketika menuliskan ukuran dan volume kotak & setiap langkah ketika menuliskan ukuran \\
sudah benar dengan cara melihat kembali & dan volume kotak sudah benar dengan cara \\
apa yang telah ditulis, menentukan syarat melihat kembali apa yang telah ditulis, & mak \\
agar volume kotak maksimum dan & menentukan syarat agar volume kotak \\
menurunkan volume kotak dan ditulis sama & maksimum dan menurunkan volume kotak \\
denga nol, menyatakan cara untuk & dan ditulis sama dengan nol, menyatakan \\
memperoleh nilai x pada turunan pertama & cara untuk memperoleh nilaix pada turunan \\
persamaan volume, yaitu dengan & pertama persamaan volume, yaitu dengan \\
\hline
\end{tabular}


memfaktorkan, menyatakan nilai $x$ yang mengakibatkan volume kotak maksimum dan menentukan cara untuk memperoleh volume maksimum, menyatakan bahwa untuk $x=10$ tidak dapat dibuat kotak yang volumenya maksimum, tidak dapat menentukan cara untuk mengecek kebenaran hasil yang diperoleh, menuliskan ukuran panjang, lebar dan tinggi kotak yang mengakibatkan volume kotak maksimum, menuliskan volume maksimum kotak, menyatakan bahwa hasil yang diperoleh sudah benar dengan cara melihat kembali apa yang ditulis, tidak dapat menyimpulkan apa yang dituliskan pada saat melaksanakan rencana pemecahan masalah. memfaktorkan, menyatakan nilai $\mathrm{x}$ yang mengakibatkan volume kotak maksimum dan menentukan cara untuk memperoleh volume maksimum, menyatakan bahwa untuk $x=15$ tidak dapat dibuat kotak yang volumenya maksimum, menentukan ukuran panjang, lebar dan tinggi kotak, menuliskan volume kotak maksimum, menyatakan bahwa jawaban yang dituliskan sudah benar, tidak dapat menyimpulkan apa yang dituliskan pada saat melaksanakan rencana pemecahan masalah.

Berdasarkan paparan data S2IP pada Tabel 7 di atas, dapat disimpulkan bahwa ada konsistensi S2IP dalam melaksanakan rencana pemecahan masalah 1 dan 2, sehingga dapat dikatakan bahwa data S2IP dalam melaksanakan rencana pemecahan masalah adalah kredibel.

\section{d. Tahap memeriksa kembali hasil pemecahan masalah}

Cuplikan hasil wawancara dan pengamatan masalah 1 dan 2 pada tahap memeriksa kembali hasil pemecahan masalah dipaparkan dan divalidasi. Validasi dilakukan untuk memperoleh data kredibel dengan cara membandingkan data hasil wawancara dan pengamatan masalah 1 dan masalah 2. Paparan dan validasi data hasil wawancara dan pengamatan masalah 1 dan masalah 2 disajikan pada Tabel 8 berikut.

Tabel 8. Paparan dan Validasi Data Hasil Wawancara dan Pengamatan Masalah 1 dan Masalah 2 pada Tahap Memeriksa Kembali Hasil Pemecahan Masalah untuk

\begin{tabular}{|c|c|}
\hline \multicolumn{2}{|c|}{ S2IP } \\
\hline $\begin{array}{c}\text { Data Hasil Wawancara dan Pengamatan } \\
\text { Tahap Memeriksa Kembali Hasil } \\
\text { Pemecahan Masalah } 1 \\
\end{array}$ & $\begin{array}{c}\text { Data Hasil Wawancara dan Pengamatan } \\
\text { Tahap Memeriksa Kembali Hasil } \\
\text { Pemecahan Masalah } 2 \\
\end{array}$ \\
\hline $\begin{array}{l}\text { Pada saat memeriksa kembali hasil } \\
\text { pemecahan masalah } 1, \text { S2IP melakukan } \\
\text { hal-hal berikut: mengungkapkan cara } \\
\text { memeriksa kembali hasil pemecahan } \\
\text { masalah, yaitu menelusuri kembali apa } \\
\text { yang sudah ditulis, menyatakan bahwa } \\
\text { cara yang dilakukan untuk memeriksa } \\
\text { kembali hasil pemecahan masalah sudah } \\
\text { benar, menyimpulkan bahwa hasil yang } \\
\text { diperoleh sudah benar. }\end{array}$ & $\begin{array}{l}\text { Pada saat memeriksa kembali hasil } \\
\text { pemecahan masalah 2, S2IP melakukan } \\
\text { hal-hal berikut: mengungkapkan cara } \\
\text { memeriksa kembali hasil pemecahan } \\
\text { masalah, yaitu menelusuri kembali apa } \\
\text { yang sudah ditulis, menyatakan bahwa cara } \\
\text { yang dilakukan untuk memeriksa kembali } \\
\text { hasil pemecahan masalah sudah benar, } \\
\text { menyimpulkan bahwa hasil yang diperoleh } \\
\text { sudah benar. }\end{array}$ \\
\hline
\end{tabular}


Berdasarkan paparan data S2IP pada Tabel 8 di atas,dapat disimpulkan bahwa ada konsistensi S2IP dalam memeriksa kembali hasil pemecahan masalah 1 dan masalah 2, sehingga dapat dikatakan bahwa data S2IP dalam memeriksa kembali hasil pemecahan masalah adalah kredibel.

\section{PEMBAHASAN}

\section{Profil Penalaran Matematis Siswa yang Bergaya Kognitif Impulsif Laki-Laki}

Pada saat memahami masalah, subjek membaca masalah dalam hati beberapa kali sampai masalah benar-benar dipahami dengan baik dan diperoleh profil penalaran matematis siswa yang bergaya kognitif impulsif laki-laki adalah sebagai berikut: menyajikan pernyataan secara lisan tentang apa yang dipahami; melakukan manipulasi matematika pada saat memahami masalah, yaitu pada saat menentukan apa yang diketahui dan yang ditanyakan pada masalah; memeriksa kebenaran argumen yang ditulis atau yang diungkapkan; tidak dapat memberikan kesimpulan tentang apa yang dipahami pada masalah yang diberikan.

Profil penalaran matematis siswa yang bergaya kognitif impulsif lakilaki pada tahap membuat rencana pemecahan masalah adalah sebagai berikut: membuat gambar sebagai representasi dari masalah; melakukan manipulasi matematis saat akan memikirkan ukuran panjang, lebar, tinggi dan persamaan volume kotak, menurunkan persamaan volume kotak; mengungkapkan bahwa apa yang dipikirkan pada saat membuat rencana pemecahan masalah sudah benar dengan alasan yang logis; tidak dapat menyimpulkan apa yang dipikirkan dalam menentukan ukuran kotak agar volume kotak maksimum.

Profil penalaran matematis siswa yang bergaya kognitif impulsif lakilaki pada tahap melaksanakan rencana pemecahan masalah adalah sebagai berikut: menyajikan pernyataan secara tertulis atau gambar tentang apa yang telah dipikirkan; melakukan manipulasi matematis pada saat menentukan ukuran kotak agar volumenya maksimum; menyatakan bahwa setiap langkah yang dituliskan sudah benar dengan cara memeriksa kembali apa yang ditulis; tidak dapat menyimpulkan tentang penyelesaian masalah yang diberikan.

Profil penalaran matematis siswa yang bergaya kognitif impulsif lakilaki pada tahap pememeriksaan kembali hasil pemecahan masalah adalah sebagai berikut: mengungkapkan cara memeriksa kembali hasil pemecahan masalah, yaitu dengan cara menelusuri kembali dari awal apa yang telah dikerjakan; tidak melakukan manipulasi matematis saat memeriksa kemabali hasil pemecahan masalah karena hanya mencermati apa yang sudah ditulis; tidak mengatakan bahwa cara memeriksa kembali hasil pemecahan masalah sudah benar; menyimpulkan bahwa hasil yang diperoleh sudah benar. 


\section{Profil Penalaran Matematis Siswa yang Bergaya Kognitif Impulsif Perempuan}

Pada saat memahami masalah, subjek membaca masalah dalam hati beberapa kali sampai benar-benar masalah dipahami dengan baik, sehingga diperoleh profil penalaran matematis siswa yang bergaya kognitif impulsif perempuan pada tahap memehami masalah adalah sebagai berikut: mengungkapkan secara lisan tentang apa yang dipahami pada masalah; melakukan manipulasi sehingga dapat menentukan apa yang diketahui dan ditanyakan pada masalah; memeriksa kebenaran apa yang dipahami pada masalah dengan cara melihat kembali masalah yang diberikan; menyimpulkan apa yang dipahami pada masalah, yaitu akan dibuat kotak tanpa tutup dari karton yang disediakan.

Profil penalaran matematis siswa yang bergaya kognitif impulsif perempuan pada tahap membuat rencana pemecahan masalah adalah sebagai berikut: membuat gambar tentang apa yang dipahami pada masalah sebagai representasi dari masalah; melakukan manipulasi matematis pada saat membuat rencana pemecahan masalah pada saat akan menentukan panjang, lebar, tinggi dan persamaan volume kotak dalam bentuk variabel; menyatakan bahwa apa yang diungkapkan pada saat membuat rencana pemecahan masalah sudah benar dengan memberikan alasan yang logis; menyimpulkan bahwa dari apa yang dipikirkan akan diperoleh kotak yang volumenya maksimum.

Profil penalaran matematis siswa yang bergaya kognitif impulsif perempuan pada tahap melaksanakan rencana pemecahan masalah adalah sebagai berikut: menyajikan pernyataan secara tertulis tentang apa yang telah dipikirkan ketika membuat rencana pemecahan masalah, yaitu dalam menentukan ukuran dan volume kotak; melakukan manipulasi matematis pada saat menentukan ukuran panjang, lebar, tinggi dan volume kotak maksimum, mengungkapkan bahwa setiap langkah yang ditulis pada saat melaksanakan rencana pemecahan masalah sudah benar dengan memberikan alasan yang logis; tidak dapat menyimpulkan apa yang dituliskan pada saat melaksanakan rencana pemecahan masalah.

Profil penalaran matematis siswa yang bergaya kognitif impulsif perempuan pada tahap memeriksa kembali hasil pemecahan masalah adalah sebagai berikut: mengungkapkan cara memeriksa kembali hasil pemecahan masalah; tidak melakukan manipulasi matematis saat memeriksa kembali hasil pemecahan masalah; mengungkapkan bahwa cara memeriksa kembali hasil pemecahan masalah sudah benar, yaitu dilakukan dengan cara mencermati kembali apa yang telah ditulis; menarik kesimpulan tentang hasil pemeriksaan kembali hasil pemecahan masalah. 


\section{E. KESIMPULAN}

Hasil penelitian ini mengidentifikasi profil penalaran matematis siswa antara laki-laki dan perempuan bergaya kognitif impulsif dalam memecahkan masalah matematika berdasarkan pentahapan Polya (1973). Pertama, pada tahap memahami masalah siswa menyajikan pernyataan secara lisan tentang apa yang dipahami pada masalah, melakukan manipulasi matematika, memeriksa kebenaran argumen yang diungkapkan dan salah satu subyek tidak menyimpulkan tentang apa yang dipahami pada masalah. Kedua, pada tahap membuat rencana pemecahan masalah siswa membuat gambar sebagai representasi dari masalah, melakukan manipulasi matematis saat memikirkan rencana pemecahan masalah, memeriksa kebenaran rencana yang dipikirkan dan tidak menyimpulkan apa yang dipikirkan dalam membuat rencana pemecahan masalah. Ketiga, dalam tahap melaksanakan rencana pemecahan masalah siswa menyajikan pernyataan secara tertulis tentang apa yang telah dipikirkan, melakukan manipulasi matematika, menyatakan kebenaran apa yang ditulis dan tidak menyimpulkan hasil pemecahan masalah. Pada tahap memeriksa kembali hasil pemecahan masalah siswa tidak melakukan manipulasi matematis saat memeriksa kembali hasil pemecahan masalah.

\section{DAFTAR PUSTAKA}

Alhojailan, M. I. (2012). Thematic analysis: A critical review of its process and evaluation. West East Journal of Social Sciences, 1(1), 39-47.

Bernard, M. (2015). Meningkatkan kemampuan komunikasi dan penalaran serta disposisi matematik siswa SMK dengan pendekatan kontekstual melalui game Adobe Flash CS 4.0. Infinity Journal, 4(2), 197-222.

Effendi, L. A. (2012). Pembelajaran matematika dengan metode penemuan terbimbing untuk meningkatkan kemampuan representasi dan pemecahan masalah matematis siswa SMP. Jurnal Penelitian Pendidikan, 13(2), 1-10.

Fennema, E. \& Hart, L. (1994). Gender and the JRME. Journal for Research in Mathematics Education, 25(6), 648-659.

Lestari, S. (2013). Proses berpikir kritis siswa dalam memecahkan masalah matematika open ended ditinjau dari kemampuan matematika siswa dan perbedaan jenis kelamin pada materi kubus dan balok. MATHEdunesa, 3(2), 1-4. 
Murtiyasa, B. (2015). Tantangan pembelajaran matematika era global. Prosiding Seminar Nasional Matematika dan Pendidikan Matematika UMS 2015.

Mudlofir, A. (2015). Profesionalisasi pendidik: mempertahankan norma kode etik dan menjawab tuntutan global. Seminar Bersama UINSA Surabaya dengan UUM Malaysia.

Nurdalilah, E. S., \& Armanto, D. (2014). Perbedaan kemampuan penalaran matematika dan pemecahan masalah pada pembelajaran berbasis masalah dan pembelajaran konvensional di SMA Negeri 1 Kualuh Selatan. Jurnal Unimed, 6(2).

Polya, G. (1973). How to solve it (2nd edition). New Jersey: Princeton University Press.

Ramdani, Y. (2012). Pengembangan instrumen dan bahan ajar untuk meningkatkan kemampuan komunikasi, penalaran, dan koneksi matematis dalam konsep integral. Jurnal Penelitian Pendidikan, 13(1), 44-52.

Sani, R. A. (2013). Inovasi pembelajaran. Jakarta: Bumi Aksara.

Sangila, M. S., \& Anggo, M. (2017). Perbedaan hasil belajar matematika ditinjau dari kombinasi model pembelajaran kooperatif dan motivasi berprestasi. Jurnal Pendidikan Matematika, 7(1), 62-79.

Sumartini, T. S. (2015). Peningkatan kemampuan penalaran matematis siswa melalui pembelajaran berbasis masalah. Mosharafa: Jurnal Pendidikan Matematika, 4(1), 1-10.

Warli. (2010). Profil kreativitas siswa yang bergaya kognitif reflektif dan siswa yang bergaya kognitif impulsif dalam memecahkan masalah matematika. Disertasi tidak diterbitkan. Surabaya: Program Pasca Sarjana Unesa.

Weaver-Hightower, M. (2003). The "Boy-Turn" in research on gender and education. Review of Educational Research, 73(4), 471-498.

Yenni, R. S. A. (2016). Analisis kemampuan penalaran matematis siswa SMP melalui model pembelajaran Numbered Head Together. Jurnal Prima, $5(2), 73-81$. 